\title{
EFFECTS OF FINANCIAL PERFORMANCE AND CORPORATE SOCIAL RESPONSIBILITY ON COMPANY VALUES: CASE OF BANKS LISTED ON THE INDONESIA STOCK EXCHANGE
}

\author{
Larey Wahongan ${ }^{1}$ \\ ${ }^{1}$ Accounting Profession Program, Economics and Business Faculty, Sam Ratulangi University, Jl. Kampus \\ Bahu, Manado, 95115, Indonesia \\ Corresponding e-mail: wahonganlarey@yahoo.com
}

\begin{abstract}
This study aims to analyze the effect of financial performance and corporate social responsibility (CSR) on the value of the company at banks listed on the Indonesia Stock Exchange for the period 2013-2017. The data used are secondary data, namely financial statements published on the Indonesia Stock Exchange's website during the period 2013-2017 which contain information about the ratio of banking financial performance (NPL, LDR, ROA, and CAR), Corporate Social Responsibility (CSR), and Value Companies with Tobin's $Q$ method. This study consists of dependent variables and independent variables. The dependent variable is the value of the company, while the independent variable is financial performance and Corporate Social Responsibility (CSR).
\end{abstract}

Keywords: financial performance, corporate social responsibility, corporate value JEL Classification : G21,G41,M14

Article info:

Received 3 July 2019

Revised 18 July 2019

Accepted 26 July 2019

Available online 31 July 2019

\section{INTRODUCTION}

Banks are the most important financial institutions that affect the economy both micro and macro. Its function is a financial intermediary between parties that are surplus and those who need funds or deficits. In running its business as a financial institution that sells trust and services, each bank strives as much as possible to attract new customers, enlarge its funds and also increase the lending and services. According to Republic of Indonesia Law Number 10 of 1998 concerning banking, banks are business entities that collect funds from the public in the form of deposits and distribute them to the public in the form of loans and / or other forms in order to improve the lives of many people. As a service company, the banking business includes three activities, namely raising funds, channeling funds, and providing other bank services. Activities to collect and channel funds are the main activities, while other activities are supporting services that function to support the smooth running of the main activities.

Basically the purpose of financial management is to maximize the value of the company. However, behind this goal there is a conflict between shareholders and managers, and with fund providers as creditors. Shareholders will tend to maximize the value of shares and force managers to act in accordance with their interests through the supervision they do. Creditors on the other hand tend to try to protect the funds they have invested in the company with strict guarantees and supervision policies. Managers also have the urge to pursue their personal interests. Even though it is possible, managers make investments even though these investments cannot maximize shareholder value. These differences of interest lead to conflicts that are often called agency conflict. 
According to Bank Indonesia Regulation (PBI) Number 13/1 / PBI / 2011 dated January 5, 2011 concerning the Evaluation of the Soundness of Commercial Banks, the assessment of bank soundness began using the RGEC method (Risk profile, Good Corporate Governance, Earnings, and Capital). With the adoption of the RGEC method, researchers want to see whether the enactment of RGEC will further enhance the value of banking companies. Financial performance, Loan to Deposit Ratio (LDR), Return on Assets (ROA), and Capital Adequacy Ratio (CAR), Corporate Social Responsibility (CSR). Company value can be influenced by two factors, namely Financial Performance which includes NPL, LDR, ROA, and CAR. Judging from Financial Performance, if a company maximizes Financial Performance (NPL, LDR, ROA, and CAR), it is expected that the Company Value can increase. On the other hand, Corporate Social Responsibility (CSR) becomes something important and must be reported by the company. CSR is a form of corporate responsibility towards social and environment as well as one of the things that is considered by investors when making investment decisions. Thus financial performance and Corporate Social Responsibility (CSR) can jointly influence the corporate values.

\section{LITERATURE REVIEWS}

This study uses a quantitative approach. Quantitative approach is an approach that uses numerical data in statistical analysis. This study is a comparative causal study, namely a research method that aims to determine the effect of independent variables on the dependent variable. In this study the dependent variable is Value Company (Tobin's Q), while the independent variables in this study are Financial Performance (NPL, LDR, ROA, CAR) and CSR. In this study, researchers used one dependent variable and five independent variables. The dependent variable used is the Company Value with the Tobin's Q method while the independent variable is Financial Performance which uses the calculation of the NPL ratio, LDR, ROA, CAR, and other independent variables, namely CSR.

\subsection{Company Value}

The formula from Tobin's Q as follows.

$$
\mathrm{Q}=\frac{\mathrm{ME}+\mathrm{DEBT}}{\mathrm{TA}}
$$

where $\mathrm{Q}$ is company value, $\mathrm{ME}$ is the number of outstanding common shares of the company multiplied by the closing price of the stock (closing price), DEBT is total debt, and TA is book value of total assets reported in financial statements and published in Indonesia Stock Exchange.

\subsection{Non Performing Loan (NPL)}

NPL is a financial ratio that shows the credit risk faced by a bank due to lending and investment of bank funds in different portfolios. This ratio can be measured using the formula:

$$
\mathrm{NPL}=\frac{\text { Total Non-performing Loan }}{\text { Total outstanding loans }} \times 100 \%
$$

\subsection{Loan to Deposit Ratio (LDR)}

Loan to Deposit Ratio (LDR) is a comparison between the total amount of credit or payment provided by the bank with funds received by the bank (Dendawijaya, 2009). This ratio can be formulated as follows: 


$$
\text { LDR }=\frac{\text { Total Loan }}{\text { Third parties funds }} \times 100 \%
$$

\subsection{Return on Asset (ROA)}

This ratio is used to measure the ability of bank management to obtain overall profits. The greater the ROA of a bank, the greater the profitability of the bank and the better the position of the bank in terms of the use of assets. This ratio can be formulated as follows:

$$
\text { ROA }=\frac{\text { Earnings before tax }}{\text { Total assets }} \times 100 \%
$$

\subsection{Capital Adequacy Ratio (CAR)}

Capital Adequacy Ratio (CAR) is a bank's performance ratio to measure the capital adequacy of a bank to support assets that contain or produce risks, for example loans given (Dendawijaya, 2009). The Capital Adequacy Ratio (CAR) ratio can be formulated as follows:

$$
\mathrm{CAR}=\frac{\text { Capital }}{\text { Risk based weighted assets }} \times 100 \%
$$

\subsection{Corporate Social Responsibility (CSR)}

Measuring CSR using the CSR disclosure index (CSRDI) is formulated as follows:

$$
\text { CSRDI }=\frac{\text { Amount of CSR disclosure }}{79 \text { information items of CSR }} \times 100 \%
$$

\section{RESEARCH METHOD}

Data collection techniques in this study were carried out by the method of documentation. The data used are secondary data, namely financial statements published on the Indonesia Stock Exchange website during the period 2013-2017 which contain information about the ratio of banking financial performance (NPL, LDR, ROA, and CAR), Corporate Social Responsibility (CSR), and Value Companies with Tobin's Q method. Additional data is obtained from other sources in the form of journals, articles, and other sources related to research. Descriptive statistical analysis is used to describe or explain the description of the object under study through sample or population data as it is, without analyzing and making conclusions that apply in general (Sugiyono, 2011: 142). Data seen from descriptive statistical analysis include average (mean), standard deviation, maximum value, minimum value and number of research data.

\section{RESULT AND DISCUSSIONS}

\subsection{Result}

\subsubsection{Descriptive Analysis}

Descriptive statistical analysis is used to provide a description of the research variables statistically in the form of minimum-maximum values, mean values, and standard deviations. Table 1 presents the results of descriptive analysis of this study. 
Table 1: Descriptive Statistics Data

\begin{tabular}{lrrrrr}
\hline \multicolumn{1}{c}{ Variable } & $\mathbf{N}$ & \multicolumn{1}{c}{ Minimum } & \multicolumn{1}{c}{ Maximum } & \multicolumn{1}{c}{ Mean } & \multicolumn{1}{c}{ Std. Deviation } \\
\hline NPL & 114 & 0,21 & 5,54 & 2,0644 & 1,08969 \\
LDR & 114 & 44,24 & 108,86 & 84,4201 & 11,53630 \\
ROA & 114 & 0,16 & 7,30 & 2,0811 & 1,08104 \\
CAR & 114 & 10,25 & 25,57 & 16,8510 & 3,01890 \\
CSR & 114 & 10,13 & 60,76 & 21,8082 & 5,80901 \\
Company value & 114 & 55,00 & 587,00 & 195,8421 & 127,66484 \\
\hline
\end{tabular}

\subsubsection{Classical Assumption Test Results}

This classic assumption test is carried out in order to obtain a regression model that can be accounted for. The classic assumption test in this study uses data normality test, multicollinearity test, autocorrelation test, and heteroscedasticity test. The results of the normality test that has been done show that the data used is not normally distributed, because it has an Asympt Sig (2- Tailed) that is smaller than the significance level of 0.05. For this reason, the author transforms the abnormal data so that Asympt Sig (2- Tailed) can be generated above 0.05 , which means that the data has a normal distribution and testing can be done.

\subsubsection{Normality Test}

The results of the normality test of the research variables indicate that all research variables have a significance value greater than 0.05 at $(0.200>0.05)$, so it can be concluded that the residuals are normally distributed.

Table 2: Result of normality test

\begin{tabular}{lcc}
\hline & Unstandardized residual & Conclusion \\
\hline Asymp. Sig, (2-tailed) & 0.200 & Normal \\
\hline
\end{tabular}

\subsubsection{Multicollinearity test}

Table 3 shows that all independent variables have tolerance values above 0.1 and VIF values below 10, so it can be concluded that the regression model in this study did not occur multicollinearity.

Table 3. Result of multicollinearity test

\begin{tabular}{lccl}
\hline Variable & Tolerance & VIF & Conclusion \\
\hline NPL & 0,883 & 1,133 & Non multicollinearity \\
LDR & 0,931 & 1,075 & Non multicollinearity \\
ROA & 0,896 & 1,117 & Non multicollinearity \\
CAR & 0,936 & 1,069 & Non multicollinearity \\
CSR & 0,903 & 1,108 & Non multicollinearity \\
\hline
\end{tabular}

\subsubsection{Autocorrelation test}

Table 4 shows the result of autocorrelation of this study. It is seen that the calculation of the Durbin-Watson value is 2.006, which means that the value between du < dw <4-du where $\mathrm{du}=1.7919$ and $4-\mathrm{du}=4-1.7919=2.2081$. This shows no autocorrelation.

Table 4. Autocorrelation Test Result

\begin{tabular}{cccc}
\hline du & 4-du & D-W value & Conclusion \\
\hline 1,7919 & $4-1,7919=2,2081$ & 2,006 & Non autocorrelation \\
\hline
\end{tabular}




\subsubsection{Heteroscedasticity Test}

Table 5 shows that none of the independent variables statistically significant affect the dependent variable value Absolute Residual (ABS_RES). This can be seen from the probability of its significance above the confidence level of 5\%. So it can be concluded that the regression model does not contain any heteroscedasticity (there is no heteroscedasticity).

Table 5. Heteroscedasticity Test Result

\begin{tabular}{lcl}
\hline Variable & Sig. & Conclusion \\
\hline NPL & 0,932 & Homoscedasticity \\
LDR & 0,556 & Homoscedasticity \\
ROA & 0,794 & Homoscedasticity \\
CAR & 0,089 & Homoscedasticity \\
CSR & 0,262 & Homoscedasticity \\
\hline
\end{tabular}

\subsubsection{Hypothesis testing}

Testing the hypothesis of this study examines the effect of independent variables on the dependent variable. The first to fifth hypothesis testing is done by a simple regression analysis technique because it only explains the effect of one independent variable and one dependent variable while the sixth hypothesis testing uses multiple regression analysis techniques because it explains the effect of two independent variables together with one dependent variable. The description of the results of the first, second and third hypotheses is explained in the following description.

\section{Testing the first hypothesis}

Table 6 presents the result of relationship between NPL and company value. The regression line equation can be expressed in the equation as follows:

$\hat{\mathrm{Y}}=233,198-18,095 \mathrm{X} 1$

This equation shows that the coefficient value of $\mathrm{X} 1$ is $-18,095$ which means that if the NPL $\left(\mathrm{X}_{1}\right)$ increases by 1 point, the company value $(\mathrm{Y})$ will decrease by 18,095 points.

Table 6. The results of a simple regression analysis of NPL on company value

\begin{tabular}{cccccc}
\hline Variable & Constant & Coefficient & $\mathbf{R}^{2}$ & $\mathbf{t}_{\text {stat }}$ & Sig. \\
\hline NPL & 233,198 & $-18,095$ & 0,024 & $-1,654$ & 0,101 \\
\hline
\end{tabular}

The results also shows that $\mathrm{R}^{2}$ is 0.024 which means Non Performing Loans (NPL) can influence Company Value (Y) by $2.4 \%$ but there is $97.6 \%$ influenced by factors or other possible variables have an effect on Company Value (Y). Based on the $t$ test for the NPL variable, the regression coefficient value obtained in the negative direction is $-18,095$. The estimated NPL variable is $t=-1,654$ with a probability of 0.101 . Significance value of 0.101 greater than 0.05. Based on the explanation above, it can be concluded that the first hypothesis which states "Non Performing Loans (NPL) has a negative and significant effect on Company Value" is rejected.

\section{Testing the second hypothesis}

Table 7 presents the result of relationship between LDL and company value. The regression line equation can be expressed in the equation as follows:

$\hat{\mathrm{Y}}=328,316-1,569 \mathrm{X} 2$

This equation shows that the $\mathrm{X} 2$ coefficient value is -1.569 , which means that if the LDR $\left(\mathrm{X}^{2}\right)$ increases by 1 point, the Company Value (Y) will decrease by 1.569 points. Based on the results of the analysis show $\mathrm{R}^{2}$ is 0.020 which means the Loan to Deposit Ratio (LDR) can influence the Company Value (Y) of $2.0 \%$; there are still $98.0 \%$ influenced by factors or other variables that are possible to influence the Company Value (Y). Based on the test for 
the LDR variable, the regression coefficient values obtained with a negative direction are 1.569. The estimated LDR variable is $t=-1.516$ with a probability of 0.132 . Significance value of 0.132 greater than 0.05 . Based on the explanation above, it can be concluded that the second hypothesis which states "Loan to Deposit Ratio (LDR) has a positive and significant effect on Company Value" is rejected.

Table 7. The results of a simple regression analysis of NPL on company value

\begin{tabular}{cccccc}
\hline Variable & Constant & Coefficient & $\mathbf{R}^{\mathbf{2}}$ & $\mathbf{t}_{\text {stat }}$ & Sig. \\
\hline LDR & 328,316 & $-1,569$ & 0,020 & $-1,516$ & 0,132 \\
\hline
\end{tabular}

\section{Testing the third hypothesis}

Table 8 presents the result of relationship between ROA and company value. The regression line equation can be expressed in the equation as follows:

$\hat{\mathrm{Y}}=52,697+68,782 \mathrm{X} 3$

This equation shows that the $X_{3}$ coefficient value is 68.782 which means that if Return on Assets (ROA) (X3) increases by 1 point then the Company Value (Y) will increase by 68.782 points. Based on the results of the analysis show $\mathrm{R}^{2}$ is 0.339 which means that Return on Assets (ROA) can affect the Company Value (Y) by 33.9\%; there are still 66.1\% influenced by factors or other variables that are possible to influence the Company Value (Y). Based on the $\mathrm{t}$ test for the ROA variable, the regression coefficient value obtained in the positive direction is 68.782 . The estimation result of the ROA variable is $t=7,583$ with a probability of 0,000 . A significance value of 0,000 is smaller than 0.05 . Based on the explanation above, it can be concluded that the third hypothesis which states "Return on Assets (ROA) has a positive and significant effect on Company Value" is accepted.

Table 8. The results of a simple regression analysis of ROA on company value

\begin{tabular}{cccccc}
\hline Variable & Constant & Coefficient & $\mathbf{R}^{2}$ & $\mathbf{t}_{\text {stat }}$ & Sig. \\
\hline ROA & 52,697 & 68,782 & 0,339 & 7,583 & 0,000 \\
\hline
\end{tabular}

\section{Testing the fourth hypothesis}

Table 9 presents the result of relationship between CAR and company value. The regression line equation can be expressed in the equation as follows:

$\hat{Y}=138.994+3.374 X 4$

This equation shows that the coefficient value of $\mathrm{X} 4$ is 3.374 which means that if the Capital Adequacy Ratio (CAR) (X4) increases by 1 point, the Company Value (Y) will increase by 3.374 points. Based on the analysis results show $\mathrm{R}^{2}$ is 0.006 which means that Capital Adequacy Ratio (CAR) is able to influence the Company Value (Y) of $0.6 \%$; there are still 99.4\% influenced by factors or other variables that may affect the Company Value (Y). Based on the $t$ test for the CAR variable obtained the regression coefficient in the positive direction of 3.374. The estimation results of the CAR variable are $t=0.847$ with a probability of 0.399 . Significance value of 0.399 greater than 0.05 . Based on the explanation above, it can be concluded that the fourth hypothesis which states "Capital Adequacy Ratio (CAR) has a positive and significant effect on Company Value" is rejected.

Table 9. The results of a simple regression analysis of CAR on company value

\begin{tabular}{cccccc}
\hline Variable & Constant & Coefficient & $\mathbf{R}^{\mathbf{2}}$ & $\mathbf{t}_{\text {stat }}$ & Sig. \\
\hline CAR & 138,994 & 3,374 & 0,006 & 0,847 & 0,399 \\
\hline
\end{tabular}




\section{Testing the fifth hypothesis}

Table 10 presents the result of relationship between CSR and company value. The regression line equation can be expressed in the equation as follows:

$\hat{Y}=143,798+2,386 X 5$

This equation shows that the coefficient value of X5 is 3.374 which means that if Corporate Social Responsibility (CSR) (X5) increases by 1 point, the Company Value (Y) will increase by 2,386 points. Based on the analysis results show $\mathrm{R}^{2}$ is 0.012 which means that Corporate Social Responsibility (CSR) is able to influence Company Value (Y) by 1.2\%; there are still 98.1\% influenced by factors or other variables that are possible to influence the Company Value (Y). Based on the $t$ test for the Corporate Social Responsibility (CSR) variable, the regression coefficient value is obtained with direction positive at 1.156. The estimation result of CSR variable is $t=1,156$ with a probability of 0,250 . Significance value of 0.250 greater than 0.05. Based on the explanation above, it can be concluded that the fifth hypothesis which states "Corporate Social Responsibility (CSR) has a positive and significant effect on Corporate Value" is rejected.

Table 10. The results of a simple regression analysis of CSR on company value

\begin{tabular}{cccccc}
\hline Variable & Constant & Coefficient & $\mathbf{R}^{\mathbf{2}}$ & $\mathbf{t}_{\text {stat }}$ & Sig. \\
\hline CSR & 143,798 & 2,386 & 0,012 & 1,156 & 0,250 \\
\hline
\end{tabular}

\section{Testing the sixth hypothesis}

Table 11 presents the results of the multiple regression with equation below. $\mathrm{Y}=187,083-2,000 \mathrm{NPL}-1,459 \mathrm{LDR}+68,449 \mathrm{ROA}-0,281 \mathrm{CAR}-0,074 \mathrm{CSR}+\mathrm{e}$ The $\mathrm{R}^{2}$ test results in this study obtained a value of 0.358 . This shows that Company Value is influenced by Financial Performance (NPL, LDR, ROA, CAR and CSR) and Corporate Social Responsibility (CSR) of $35.8 \%$, while the remaining $64.2 \%$ is influenced by other factors not examined in the study this. Based on the test results, the F value is 12,046 with a significance of 0,000 . It turns out that the significance value is smaller than $0.05(0,000$ $<0,05)$, this means that the model can be used to predict the influence of Financial Performance (NPL, LDR, ROA, CAR and CSR) and Corporate Social Responsibility (CSR) on Value Banking sector companies in the Indonesia Stock Exchange 2013-2017 period.

Table 11. Results of multiple regression analysis

\begin{tabular}{|c|c|}
\hline Variable & Coefficient \\
\hline Constant & 187,083 \\
\hline NPL & $-2,000$ \\
\hline LDR & $-1,459$ \\
\hline ROA & $68,449 * * *$ \\
\hline CAR & $-0,281$ \\
\hline CSR & $-0,074$ \\
\hline $\mathrm{R}^{2}$ & 0,358 \\
\hline $\mathrm{F}$ & $12,046 * * *$ \\
\hline
\end{tabular}

\subsection{Discussion}

4.2.1. Effect of Non Performing Loans (NPL) on Corporate Values

The results of the t-test statistic for the NPL variable obtained a regression coefficient in the negative direction of $-18,095$. The estimated NPL variable is $t=-1,654$ with a probability of 0.101 . Significance value of 0.101 greater than 0.05 . Based on the explanation 
on above, it can be concluded that Non Performing Loans (NPL) have a negative and not significant effect on Company Value.

\subsubsection{Effect of Loan to Deposit Ratio (LDR) on Company Values}

The results of the t-test statistic for the LDR variable obtained a regression coefficient with a negative direction of -1.569 . The estimated LDR variable is $\mathrm{t}=-1.516$ with a probability of 0.132 . Significance value of 0.132 greater than 0.05 . Based on the explanation above, it can be concluded that the Loan to Deposit Ratio (LDR) has a negative effect and is not significant to the company value.

\subsubsection{Effect of Return on Assets (ROA) on Corporate Values}

The results of the t-test statistic for the ROA variable obtained a regression coefficient with a positive direction of 68.782. The estimation result of the ROA variable is $t=7,583$ with a probability of 0,000 . A significance value of 0,000 is smaller than 0.05 . Based on the explanation above, it can be concluded that Return on Assets (ROA) has a positive and significant effect on Firm Value. The results of the study indicate that Return on Assets (ROA) has a positive and significant effect on Company Value. Return On Assets (ROA) is a ratio used to measure the ability of bank management to obtain profitability and manage the overall level of business efficiency of the bank. The greater the value of this ratio shows the level of business profitability of the bank is getting better or healthier (Prasnanugraha, 2009). This ratio can be used as a measure of financial health. a bank. The greater the ROA, the greater the level of profit achieved by the bank so that it is less likely that a bank will occur in a problematic condition. Thus, ROA can increase the Value of the Company.

\subsubsection{Effect of Capital Adequacy Ratio (CAR) on corporate values}

The results of the t-test statistic for the CAR variable obtained a regression coefficient with a positive direction of 3.374. The estimation results of the CAR variable are $t=0.847$ with a probability of 0.399 . Significance value of 0.399 greater than 0.05 . Based on the explanation above, it can be concluded that Capital Adequacy Ratio (CAR) has a positive and not significant effect on Company Value. The results of this study support the previous research conducted by Srihayati (2015) on "The Influence of Banking Financial Performance on Corporate Values with Tobin's Q Method on Banking Companies in Kompas 100 Listing (Period 2009-2013)". The results of the study prove that partially not available significant effect of banking financial performance in terms of CAR on Company Value. The results of the study show that the Capital Adequacy Ratio (CAR) has no effect on Company Value due to the BI regulation which requires banks to maintain CAR with a minimum of $8 \%$. This is in accordance with the opinion of Dendawijaya (2005) who said that if the value of CAR is high (in accordance with Bank Indonesia provisions of 8\%) it means that the bank is able to finance bank operations, and the favorable conditions can contribute significantly to the bank's profitability ( ROA) concerned. As a result, the bank must prepare a reserve fund to meet the minimum requirements in addition to anticipating credit risk. The bank's investment policy which carefully invests funds will affect the value of the bank's company. In addition, the level of public trust is also one of the important factors that influence the value of bank companies. Therefore, even though banks have high capital and a high level of CAR, if it is not balanced with investment and good funding, CAR will not have much effect on the value of the company.

\subsubsection{Effect of Corporate Social Responsibility (CSR) on Corporate Values}

The results of the t-test statistic for CSR variables, obtained a regression coefficient with a negative direction of 1.156 . The estimation result of CSR variable is $t=1,156$ with a probability of 0,250 . Significance value amounting to 0.250 greater than 0.05 . Based on the explanation above, it can be concluded that Corporate Social Responsibility (CSR) has a positive and not significant effect on Company Value. Corporate Social Responsibility (CSR) is a form of corporate responsibility to improve social and environmental problems that occur 
as a result of the company's operational activities. Therefore, CSR plays an important role in increasing the value of the Company. Heinken et. Al (2001) in Gusti Ayu Made Ervina Rosiana, Gede Juliarsa and Maria M. Ratna Sari (2013) revealed that CSR must be considered as a long-term strategy that would benefit the company, not as a detrimental activity. In addition, Anis Chariri (2008) argues that companies can conduct CSR disclosures as managerial tools in terms of preventing social and environmental problems.

\subsubsection{Effect of financial performance and corporate social responsibility towards corporate value}

Based on the test results, the $F$ value is 12,046 with a significance of 0,000 . It turns out that the significance value is smaller than $0.05(0,000<0,05)$, this means that the model can be used to predict the influence of Financial Performance (NPL, LDR, ROA, and CAR) and corporate social responsibility (CSR) on value banking sector companies on the Indonesia Stock Exchange for the period 2013-2017. Samuel (2000) in Rika and Islahudin (2008) explains that enterprise value (EV) or firm value is an important concept for investors. Enterprise value (EV) or firm value becomes a market indicator in evaluating the company as a whole. Company value can be influenced by two factors, namely Financial Performance which includes NPL, LDR, ROA, and CAR. Judging from Financial Performance, if a company maximizes Financial Performance (NPL, LDR, ROA, and CAR), it is expected that Corporate Value can increase. On the other hand, Corporate Social Responsibility (CSR) becomes something important and must be reported by the company. CSR becomes a form of corporate responsibility towards social and environment as well as one of the things that happens investor's consideration when making an investment decision. Thus financial performance and corporate social responsibility (CSR) can jointly influence the corporate value.

\section{CONCLUSION}

The research conducted aims to determine the effect of Financial Performance and Corporate Social Responsibility (CSR) on the Corporate Value of the banking sector in the Indonesia Stock Exchange for the period 2013-2017. The type of data used in this study is secondary data. Data obtained from financial statements published on the Indonesia Stock Exchange website during the period 2013-2017 which contains information about the financial performance ratio of the bank, corporate social responsibility, and company value. The population used is a banking sector company listed on the Indonesia Stock Exchange for the period 2013-2017, amounting to 43 companies with a total sample of 25 companies. The sampling in this study uses purposive sampling, namely sampling with certain criteria that have been predetermined.

There are effects of financial performance (NPL, LDR, ROA, CAR and CSR) and Corporate Social Responsibility (CSR) on the Corporate Value of the banking sector in the Indonesia Stock Exchange for the period 2011-2015. This is evidenced by the F value of 12.046 with a significance of 0.000 . The $\mathrm{R} 2$ test results in this study obtained a value of 0.358. This shows that corporate value is influenced by financial performance (NPL, LDR, ROA, and CAR) and corporate social responsibility (CSR) of $35.8 \%$, while the remaining $64.2 \%$ is influenced by other factors not examined in this study.

\section{REFERENCES}

A.B. Susanto. (2009). Reputation-Driven Corporate Social Responsibility (Pendekatan Strategic Management dalam CSR).Jakarta : Esensi. 
Achmad, T. \& Kusumo, W.K. (2003).Analisis Rasio-Rasio Keuangan sebagai Indikator dalam Memprediksi Potensi Kebangkrutan Perbankan di Indonesia.Media Ekonomi \& Bisnis, 15(1).

Ali, M. (2004).Asset Liability Management (Menyiasati risiko pasar danrisiko operasional dalam perbankan).Jakarta: Elex Media Komputindo.

Alifah, Y. B. (2014). Pengaruh CAR, NPL, BOPO dan LDR pada Perusahaan Perbankan yang terdaftar di Bursa Efek Indonesia Periode 2009-2012.Skripsi.Yogyakarta: FE Universitas Negeri Yogyakarta.

Anis Chariri (2008).“Kritik Sosial atas Pemakaian Teori dalam Penelitian Pengungkapan Sosial dan Lingkungan.Jurnal Maksi.Volume 8 Nomor 2: 151-169.

Bagiani Alifah Yonira. (2014). Pengaruh CAR, NPL, BOPO, dan LDR Terhadap Profitabilitas Bank (ROA) pada Perusahaan Perbankan yang Terdaftar di Bursa Efek Indonesia Periode 2009-2012.Forum Penelitian. Yogyakarta.

Bank Indonesia. (1997). Surat Keputusan Direksi Nomor 30/12/KEP/DIR Tanggal

30 April 1997 untuk BPR.(http://www.bi.go.id, di akses 12 Maret 2017).

(1998). Undang-Undang Republik Indonesia Nomor 10 Tahun 1998. . (2001). Peraturan Bank Indonesia Nomor 13/1/1PBI/2011Tentang Penilaian Tingkat Kesehatan Bank Umum.(http://www.bi.go.id, di akses 12 Maret2017).

Brigham dan Houston. (2010). Dasar-Dasar Manajemen Keuangan (Essentials Of Financial Management) Edisi 11 Buku 1. Jakarta : Salemba Empat.

Cholid Narbuko dan H.Abu Achmadi.Metodologi Penelitian.Jakarta: Bumi Aksara.

Danang Suyonto.(2011). Analisis Regresi dan Uji Hipotesis. Yogyakarta: CAPS.

Muljono, T.P. (1999). Aplikasi Akuntansi Manajemen Dalam Praktek Perbankan (Edisi 3). Yogyakarta: BPFE.

Mulyanita, Sugesti. (2009). Pengaruh biaya tanggung jawab sosial perusahaan terhadap kinerja perusahaan perbankan. Skripsi. Universitas Negeri Lampung.

Munawir, S. (2002).Analisis Laporan Keuangan. Yogyakarta: Liberty

Nilai Perusahaan dengan Prosentase Kepemilikan Manajemen sebagai Variabel Moderating (Studi Empiris Pada Perusahaan yang Terdaftar di Bursa Efek Jakarta). Proceeding. Simposium Nasional Akuntansi XI. 23-24 Juli 2008. Pontianak

Ni Wayan Rustiarini.(2010). Pengaruh corporate governance pada hubungan corporate social responsibility dan nilai perusahaan. Proceeding.Simposium Nasional Akuntansi XIII Purwokerto.

Niyanti Anggitasari. (2012). Pengaruh kinerja keuangan terhadap nilai perusahaan dengan pengungkapan corporate social responsibility dan struktur good corporate governance sebagai variabel pemoderasi. Skripsi. Universitas Diponegoro.

Nurdizal M. Rachman, Asep Efendi, dan Emir Wicaksana. (2011). Panduan Lengkap Perencanaan CSR.Jakarta : Penebar Swadaya.

Rika Nurlela dan Islahudin.(2008). "Pengaruh Corporate Social Responsibility Terhadap Nilai Perusahaan Dengan Prosentase Kepemilikan Manajemen Sebagai Variabel Moderating (Studi Empiris Pada Perusahaan Yang Terdaftar di Bursa Efek Jakarta)".Proceeding.Simposium Nasional Akuntansi XIPontianak.

Siamat, D. (2005). Manajemen Lembaga Keuangan. Edisi Keempat. Jakarta: Badan Penerbit Fakultas Ekonomi Universitas Indonesia.

Simorangkir, O.P. (2004). Pengantar Lembaga Keuangan Bank dan Nonbank. Jakarta: Ghalia Indonesia.

Sisca Christianty Dewi.(2008). "Pengaruh Kepemilikan Manajerial, Kepemilikan Institusional, Kebijakan Utang, Profitabilitas, dan Ukuran Perusahaan terhadap Kebijakan Dividen”.Jurnal Bisnis dan Akuntansi, 10(1), hlm.47-58. 